\section{Communication :}

a Philosophical Study of Language. By Karl Britton. (International Library of Psychology, Philosophy and Scientific Method.) Pp. xvi + 290. (London : Kegan Paul and Co., Ltd., 1939.) 12s. 6d. net.

I ANGUAGE has become again a central point of L interest for philosophers, logicians and psychologists. Historically this has always been the case when thinkers begin to question the reality of values and the import of the ultimate principles of explanation of the world. The Greek sophists, the medieval nominalists, Hobbes, the eighteenth century sensualists, and the modern positivists are in the direct lineage of the contemporary analytical philosophers who make of language the leading real problem of knowledge. From this angle, Mr. Britton's book is of particular importance, in so far as it retraces in an orderly fashion the manifold cross-currents which enrich the field of logical controversy.

It begins with a discussion of four principal kinds of language : the language of empirical propositions, necessary principles, moral judgments, and poetry ; and it endeavours to show that all these can be explained in terms of the informative and of the emotive function of language. When a language refers to what we may experience, it is informative; otherwise it is emotional. It is easy to confuse informative and emotive uses of words ; and the chief object of analysis would be to distinguish these clearly. One of the results of the analysis is to show the place of necessary rules in linguistic behaviour, never to indicate the mutual relevance of psychology and logic. Mr. Britton discusses these problems with competence and skill. He also discusses the views of many recent writers, including Russell, Moore, Wisdom, Empson, Sheffer, Lewis, Wittgenstein and Carnap. Hence the interest of this volume, which may be read as an excellent introduction to the theory and practice of modern logical analysis.

The r938 Mental Measurements Year-book of the School of Education, Rutgers University

Oscar Krisen Buros, Editor. Pp. $\mathrm{xv}+415$. (New Brunswick, N. J. : Rutgers University Press, 1938.) 3 dollars.

THE output of mental tests is now so great that no worker in educational psychology can hope to know more than a small fraction of them. The seriousness of the problem for the conscientious teacher of educational psychology or director of research in that subject is not lightened by the consideration that most of the tests produced are of little or no value, for it has become almost impossibly difficult for him to discover what are the useful new tests and which are worthless.

The fact that this Year-book lists 312 new tests makes it useful to every worker in educational psychology. If it merely did that, it would only be one more of the too numerous psychological publications which preserve equally the valuable and the worthless in psychological production. In fact, it does much more since it contains a critical evaluation of all the tests and the publications on educational psychology which are described. This feature makes it invaluable. It is excellent to see at the end of the description of a test : "these tests serve to increase the number of mediocre tests that are now on the market, without making any scientific contribution to the development of group testing of intelligence". Whether or not this criticism is just in the particular case to which it is applied, it shows the right spirit. Let us hope that this Year-book marks the end of the period of merely listing psychological work without attempting to distinguish the bad from the good.

R. H. T.

\section{The Wild Asses:}

a Journey through Persia. By W. V. Emanuel. Pp. $352+12$ plates. (London: Jonathan Cape, Ltd., 1939.) 12s. $6 d$. net.

HERE Mr. Emanuel records a journey through H Persia of a mixed party, described on one occasion by Reuter as of "undergraduates". Though the author repudiates this designation, it does in some degree characterize them and their spirit of adventure. They belonged to the National Union of Students. Their route lay across Europe to Russia, and through the Caucasus into Persia, which they traversed to Meshed; and there they crossed the Afghan frontier for a brief stay at Herat. On their return they crossed the great Salt Desert of Persia, to their edification, if discomfort. Although this record is not intended to be in any sense a scientific study - anything in that nature is precluded by the rapidity with which the party travelled-the author has a keen eye for the distinctive characters of both peoples and places; and the freshness of his point of view and the acuteness of his observation give his book something more than a passing interest. It may be noted that the points which impressed him most in Persia were the sophistication of Persian people and society and the penetration of the Germans everywhere, especially in business, education and military matters.

Quelques Techniques actuelles en physique nucleaire Methode de la Trochoïde; Electrons positifs; Spectrographie de Masse; Isotopes; Compteurs de Particules a Amplification linéaire; Compteurs de Geiger et Müller. Par Prof. Jean Thibaud, Louis Carta et Paul Comparat. Pp. vi $+276+12$ plates. (Paris: Gauthier-Villars, 1938.) 100 francs.

$T$ HE greater part of this volume is devoted to a critical study of methods in mass-spectrography, and more particularly of the methods and results of the work of the last four or five years. This section, therefore, forms a valuable and needed supplement to the standard treatise of Aston. The remaining sections deal in considerable detail with the construction and uses of counters and counting circuits. Within these somewhat severely prescribed limits the treatment is remarkably complete, and it is typically French in its lucidity. The book, which is lavishly illustrated, is a notable addition to the literature of the experimental part of nuclear physics. 